GROWING UPMUSLIM 



\section{GROWING UPMUSLIM}

\section{Muslim College Students in America Tell Their Life Stories}

Andrew Garrod and Robert Kilkenny Introduction by Eboo Patel 


\section{Copyright () 2014 by Cornell University}

All rights reserved. Except for brief quotations in a review, this book, or parts thereof, must not be reproduced in any form without permission in writing from the publisher. For information, address Cornell University Press, Sage House, 512 East State Street, Ithaca, New York 14850.

First published 2014 by Cornell University Press

First printing, Cornell Paperbacks, 2014

Printed in the United States of America

Library of Congress Cataloging-in-Publication Data

Growing up Muslim in America (Garrod and Kilkenny)

Growing up Muslim : Muslim college students in America tell their life stories / edited by Andrew Garrod and Robert Kilkenny ; introduction by Eboo Patel.

$$
\text { pages } \mathrm{cm}
$$

ISBN 978-0-8014-5252-9 (cloth : alk. paper)

ISBN 978-0-8014-7915-1 (pbk. : alk. paper)

1. Dartmouth College-Students-Biography. 2. Muslim college students-New Hampshire-Hanover-Biography. 3. Muslim youth-Education (Higher) - New HampshireHanover. I. Garrod, Andrew, 1937- editor of compilation. II. Kilkenny, Robert, editor of compilation. III. Ahmed, Zahra. Far from getting lost. IV. Title.

LD1435.45.G76 2014

$378.1^{\prime} 9828297-\mathrm{dc} 23 \quad 2013037424$

Cornell University Press strives to use environmentally responsible suppliers and materials to the fullest extent possible in the publishing of its books. Such materials include vegetable-based, low-VOC inks and acid-free papers that are recycled, totally chlorine-free, or partly composed of nonwood fibers. For further information, visit our website at www.cornellpress.cornell.edu.

Cloth printing $\begin{array}{llllllllll}10 & 9 & 8 & 7 & 6 & 5 & 4 & 3 & 2 & 1\end{array}$

Paperback printing 
In recognition of their courage, hard work, self-understanding, and inspirational life stories, this book is dedicated to the twelve student autobiographers whose essays are presented here.

\author{
Marzuq Muhammad \\ Harun Hasanagić \\ Abdoul Mujyambere \\ Jeannine Uwase \\ Mouhamad Nshimiyimana \\ Mokhless Bouzayen \\ AG
}


